\title{
A Rhetorical Perspective on Nordicness: From Creating Unity to Exporting Models
}

In 2020 the dairy company Arla launched a new range of plant-based drinks. Marketed under the brand name "JÖRĐ” with allusions to Old Norse mythology, the products were described as an "oat drink from Nordic nature... made by Nordic wind, rain and sun." The term "Nordic" featured prominently in the company's own descriptions of its product, with references to "Nordic flavours such as barley and hemp," and to oats "grown in the Nordics for hundreds of years."1 This apparently trivial example picks up on real and mythical sediments of meaning at the same time as it tries to convey an image of something modern and humorous. The brand itself may be full of contradictions, especially as the Nordic countries are known for their high levels of consumption and production of dairy products, but the notion of Nordicness clearly carries a lot of rhetorical appeal in this type of marketing.

There are many other examples of the use of "the Nordic" to evoke interest in the politics, society, and culture of Denmark, Finland, Iceland, Norway and Sweden - the five countries, which together with the three autonomous regions of the Faroe Islands, Greenland, and Aland make up the Nordic region. ${ }^{2}$ In this book, we explore the appeal and flexibility of the rhetoric of Nordicness. What, if anything, do the different uses of "Nordic" have in common, and are there any particular circumstances or historical periods in which the rhetoric has been particularly popular? The starting point for our book is our perception that there has been an upsurge in a new rhetoric of Nordicness since about 2010, which so far has not been discussed in scholarly literature in any great detail. ${ }^{3}$ What accounts

1 Arla Foods, “JÖRĐ Oat Drink | Fresh \& Organic,” accessed December 13, 2020, https://jordplantbased.com/en-gb/oat-drink/.

2 Examples include The Economist's 2013 special issue on "The Nordic Countries: The Next Supermodel"; and the wave of literature on the Nordic way of life and political culture - see Anu Partanen, The Nordic Theory of Everything: In Search of a Better Life (New York: Harper Collins, 2016) or Brontë Aurell, Anna Jacobsen, and Lucy Panes, Nørth: How to Live Scandinavian (London: Aurum Press, 2017). There are also examples of attempts to brand design as Nordic (e.g. https://www.warmnordic.com/) and there is even a local brewery in Tampere that makes "Nordic beers" (see: https://www.gastropub.net/brewery/).

3 We are, however, aware of the fact that the rising appeal of "the Nordic" is also a feature of academic policy that has generated funding opportunities for scholarly research on Norden. This publication and its authors are therefore, at least to some extent, part of the phenomenon we 
for the recent rise of "the Nordic" in politics, culture and marketing, and how does this new Nordicness relate to the history of the adjective?

If one were to describe what makes the Nordic countries Nordic a wide range of characteristics could be listed. These include notions of sparsely populated societies living in close relationship to nature, comparatively peaceful and consensual political cultures, or the strong, even dominant role of the state and the weak position of the family in societal affairs. One could also highlight some of the many paradoxes of Nordicness: the strong but secularised position of religion in society, the political traditions of equality against the competitiveness of the Nordic economies, or the peripherality of relatively poor peasant societies surviving in harsh conditions against rich and modern societies blessed with an abundance of natural resources. The list of distinguishing features might draw on geography, language, culture or politics, but cannot really be complete. Indeed, definitions of "the Nordic" seldom aim at being exhaustive but are more likely to provide different sets of characteristics that produce tailored descriptions of the region. They represent competing visions of what the Nordic region is or should be.

It is also legitimate to question whether any of the defining features associated with "the Nordic" can be said to be exclusively Nordic. The Nordics share historical legacies with the Baltic States, and many political features with other small and medium-sized states, such as the Netherlands, Switzerland, New Zealand or Scotland. Many cultural, religious and political traditions in the Nordic region have a German origin, while since the Second World War, the Nordics have oriented themselves heavily towards the Anglo-American world. In their peculiar outside/inside perspective on "Europe," Nordic societies are very similar to other semi-peripheries of Europe, such as the Balkans. ${ }^{4}$ When it comes to climate and nature, the Nordics might look like parts of Canada or Russia.

Moreover, it is seldom the case that all Nordic countries share the same characteristics, a realisation that has led welfare state scholars to refer to a Nordic welfare model with five exceptions. ${ }^{5}$ This perspective highlights tensions present

study. We wish to thank the Academy of Finland (grant 323489), the NordForsk-funded university hub ReNEW, the Independent Research Fund Denmark (grant number 8018-00023B), and UiO: Nordic for their support of our research.

4 Stefan Nygård, Johan Strang, and Marja Jalava, eds., Decentering European Intellectual Space (Leiden: Brill, 2018).

5 Niels Finn Christiansen and Klaus Petersen, "Preface," Scandinavian Journal of History 26, no. 3 (September 2001): 153-156, doi:10.1080/034687501750303828; see also Jóhann Páll Árnason and Björn Wittrock, eds., Nordic Paths to Modernity (New York: Berghahn Books, 2012). 
in any notion of the Nordic. ${ }^{6}$ The old kingdoms (Sweden and Denmark) can be contrasted with the younger nation states (Norway, Finland and Iceland). The historical legacies of the early modern monarchies can be found in differences between East Norden (Sweden and Finland) and West Norden (Denmark, Norway, and Iceland), while the core Scandinavian countries (Sweden, Denmark, and Norway) may be contrasted with Iceland and Finland, or the large countries (Finland, Sweden, Denmark, and Norway) with the much smaller Iceland. There is also the notion of the more continental European Denmark versus the more peripheral parts of Norden. International political affiliations are also complex, with divisions between the NATO members (Denmark, Norway, and Iceland) and the non-aligned (Sweden and Finland); and between EU members (Denmark, Sweden, and Finland) and non-EU members (Norway and Iceland). As well as the five nation states the Nordic region also includes the autonomous territories of Greenland, the Faroe Islands and Åland, the transnational Sápmi region, which spans the northern parts of the Nordic countries and the Kola Peninsula of Russia, and border regions such as the Torne valley, the Øresund region and Southern Jutland/Schleswig.

Linguistic divisions can be made between the three Scandinavian languages, Danish, Norwegian, and Swedish - which have various degrees of mutual intelligibility - and Icelandic and Faroese, which are insular versions of Scandinavian languages no longer comprehensible to speakers of Danish, Norwegian, and Swedish. Finnish is of completely different origin, though it has been claimed that there are semantic similarities between Finnish and Swedish as political languages. ${ }^{7}$ Other non-Scandinavian languages in the region include Greenlandic and the Sámi languages. ${ }^{8}$ But there are also many languages - such as Arabic, English, and Russian, to name only a few of the most important ones - that may be widely spoken in the region, even though they are not always associated with it. Indeed, intra-Nordic communication is to an increasing extent taking place in English, which further complicates the idea of language being the core and essence of Nordicity.

6 Jani Marjanen, “Nordic Modernities: From Historical Region to Five Exceptions," International Journal for History, Culture and Modernity 3, no. 1 (March 2015): 91-106, doi:10.18352/ 22130624-00301005; Pauli Kettunen, "Review Essay: A Return to the Figure of the Free Nordic Peasant,” Acta Sociologica 42, no. 3 (July 1999): 259-269, doi:10.1177/000169939904200306.

7 Henrik Stenius, "The Finnish Citizen: How a Translation Emasculated the Concept," Redescriptions: Yearbook of Political Thought, Conceptual History and Feminist Theory 8 (2004): 172-188.

8 Michael P. Barnes, “Linguistic Variety in the Nordics,” 2019, https://nordics.info/show/artikel/ linguistic-variety-in-the-nordic-region/. 
Regardless of the complicated answers to what makes Norden Nordic, there is one point that remains: throughout at least the past two hundred years or so, many actors have invested heavily in the notion of Norden. Because of this, there is a long and complicated history of defining the Nordic region and talking about things as Nordic. The aim of this book is to analyse the broad variety of ways in which "Nordic" has been used as an adjective both within and outside the region. We explore the use of the term "Nordic" - and the related term "Scandinavian" - in conjunction with concepts such as race, openness, gender equality, food, crime fiction, Nordic cooperation, and the Nordic model, from historical and contemporary perspectives. The leading idea is that all of these uses of the term Nordic have been crucial in negotiating what the region stands for, its identity or brand. By analysing the background, context, and rhetorical struggles for the claims for specific "Nordic" characteristics in different discourses, this book sheds new light on the debates on the cultural construction of the Nordic region, ${ }^{9}$ as well as the broader international discussion on regionalism and transnational history. ${ }^{10}$

This book is part of a recent wave of volumes on Nordic societies and cultures, covering topics such as the Nordic model, Nordic egalitarianism, Nordic human rights, Nordic democracy, Nordic gender equality, Nordic literature, and Nordic design. ${ }^{11}$ Some volumes even explicitly focus on the discourse and

9 Øystein Sørensen and Bo Stråth, eds., The Cultural Construction of Norden (Oslo: Scandinavian University Press, 1997); Árnason and Wittrock, Nordic Paths to Modernity; Johan Strang, ed., Nordic Cooperation: A European Region in Transition (London: Routledge, 2016), doi:10.4324/ 9781315755366.

10 See e.g. James Casteel, "Historicizing the Nation: Transnational Approaches to the Recent European Past," in Transnational Europe: Promise, Paradox, Limits, ed. Joan DeBardeleben and Achim Hurrelmann (London: Palgrave Macmillan, 2011), 153-169, doi:10.1057/ 9780230306370_9; M. Middell, L. Roura Aulinas, and Lluís Roura i Aulinas, eds., Transnational Challenges to National History Writing (Basingstoke: Palgrave Macmillan, 2013); Diana Mishkova and Balázs Trencsényi, eds., European Regions and Boundaries: A Conceptual History (New York: Berghahn Books, 2017); Diana Mishkova, Balázs Trencsényi, and Marja Jalava, eds., "Regimes of Historicity" in Southeastern and Northern Europe, 1890-1945: Discourses of Identity and Temporality (Basingstoke: Palgrave Macmillan, 2014), doi:10.1057/9781137362476; Stefan Troebst, "Introduction: What's in a Historical Region? A Teutonic Perspective," European Review of History: Revue Europeenne d'histoire 10, no. 2 (2003): 173-188, doi:10.1080/1350748032000140741; Maria Todorova, Imagining the Balkans (New York: Oxford University Press, 1997); Maria Todorova, “Spacing Europe: What Is a Historical Region?” East Central Europe 32, no. 1-2 (2005): 59-78, doi:10.1163/18763308-90001032.

11 Anu Koivunen, Jari Ojala, and Janne Holmén, ed., The Nordic Economic, Social and Political Model: Challenges in the 21st Century (London: Routledge, 2021); Synnove Bendixsen, Mary Bente Bringslid, and Halvard Vike, eds., Egalitarianism in Scandinavia: Historical and Contempo- 
conceptualisation of these phenomena, like the recent The Changing Meanings of the Welfare State: Histories of a Key Concept in the Nordic Countries. ${ }^{12}$ However, the scholarly emphasis in all of these volumes is on the Nordic version, and the appropriation or conceptualisation of particular phenomena, rather than on the explicit historical discourses in which these phenomena have been labelled Scandinavian or Nordic. As such, our volume is most closely related to the 2010 book Rhetorics of Nordic Democracy, which tried to describe not only the elements that are so often seen as key features of Nordic politics and culture, but also the tensions that are present in the historical and discursive construction of them as Nordic. ${ }^{13}$ In comparing the rhetoric of Nordicness in a wide variety of discourses, our book is the first scholarly volume to put the focus on the adjective "Nordic" rather than the nouns that are used following it.

The starting point for the volume is the simple observation that "Nordic" and "Scandinavian" are flexible and contested concepts that have been, and continue to be, used in many and often contradictory ways. They have been associated with political projects and institutions (Scandinavianism, the Nordic Council) while also functioning as categories of analysis in academic research (the Nordic model, Nordic welfare states). Moreover, they have been used to pinpoint a regional identity, based on shared historical and cultural legacies, which is often said to complement, rather than compete with, the national identities in the region. "Nordic" and "Scandinavian" have often - though not always - had positive connotations. As such, they have to an increasing extent become resources for commercial and cultural branding, as in the examples of Nordic noir, New Nordic Food or Scandinavian design. The chapters of the book discuss in-

rary Perspectives (London: Palgrave Macmillan, 2018), doi:10.1007/978-3-319-59791-1; Hanne Hagtvedt Vik et al., eds., Nordic Histories of Human Rights (London: Routledge, 2021); Nicholas Aylott, Models of Democracy in Nordic and Baltic Europe: Political Institutions and Discourse (Farnham: Ashgate Publishing, 2014); Eirinn Larsen, Sigrun Marie Moss, and Inger Skjelsbæk, eds., Gender Equality and Nation Branding in the Nordic Region (London: Routledge, 2021); Steven P. Sondrup et al., eds., Nordic Literature: A Comparative History, Vol. 1, Spatial Nodes (Amsterdam: John Benjamins Publishing Company, 2017), doi:10.1075/chlel.xxxi; Tobias Hoffmann and Bröhan-Museum Berlin, eds., Nordic Design: Die Antwort aufs Bauhaus = Nordic Design: The Response to the Bauhaus (Stuttgart: Arnoldsche, 2019); Byrkjeflot, Haldor, Lars Mjøset, Mads Mordhorst and Klaus Petersen, eds. The Making and Circulation of Nordic Models, Ideals and Images (London: Routledge, 2021) doi:10.4324/9781003156925.

12 Nils Edling, ed., The Changing Meanings of the Welfare State: Histories of a Key Concept in the Nordic Countries (New York: Berghahn Books, 2019).

13 Jussi Kurunmäki and Johan Strang, "Introduction: 'Nordic Democracy' in a World of Tensions,” in Rhetorics of Nordic Democracy, ed. Jussi Kurunmäki and Johan Strang (Helsinki: Finnish Literature Society, 2010), doi:10.21435/sfh.17. 
dividual cases, but this introduction will present our methodological starting point, discuss a number of key tensions in the rhetoric of Nordicness, and, finally, highlight a number of key turning points and historical layers in this rhetoric.

\section{"Nordic" as a contested concept}

The overwhelming appeal of the term "Nordic" during the twenty-first century has made it an object of political struggle between various groups who seek to claim the term for their own purposes. During the 2010s, for example, the Nordic model was at the centre of such disputes between Social Democrats and Conservatives across the region (see Hilson and Hoctor in this volume). At the same time another rhetoric of Nordicness with nationalist, anti-immigration and even racist overtones also flourished: at the time of writing in 2021 the populist party group in the Nordic Council calls itself "Nordic Freedom" (Nordisk frihed), while extreme right-wing movements such as the "Nordic Resistance Movement" (Nordiska motståndsrörelsen) make frequent use of Old Norse mythology. Yet, Nordicness also continues to be evoked in the name of international solidarity, humanitarianism and solidarity, as for example with the New Nordic Peace report published by the Nordic Council of Ministers in 2019. ${ }^{14}$ Indeed, in May 2015 the Finnish Social Democrat Erkki Tuomioja criticised a government decision to make record-breaking cuts in foreign aid by claiming that "Finland is no longer a Nordic country." 15

If notions of Nordicness are contested in the present, they were certainly never fixed in the past. As shown in Merle Weßel's chapter, the concept of a Nordic race was widespread among scientists and politicians in the United States, Europe and Scandinavia during the late nineteenth and early twentieth centuries. The adjective "Nordic" was used politically in the 1930s by the German National Socialists as well as by the far right within the Nordic region. The Swedish National Socialists of the 1930s, for example, called their youth organisation "Nordic Youth" (Nordisk Ungdom). At the same time, the 1930s saw the dawn of a rhetoric of "Nordic democracy" by which Social Democrats and others sought to portray the region as a democratic haven in a Europe threatened by totalitarianism. ${ }^{16}$

14 Anine Hagemann and Isabel Bramsen, New Nordic Peace 524, TemaNord (Copenhagen: Nordic Council of Ministers, 2019), doi:10.6027/TN2019-524.

15 Cecilia Heikel, "Vi använder vår yttrandefrihet för att säga ifrån,” Svenska Yle, July 28, 2015, https://svenska.yle.fi/artikel/2015/07/28/vi-anvander-var-yttrandefrihet-att-saga-ifran.

16 Kurunmäki and Strang, “Introduction: 'Nordic Democracy' in a World of Tensions.” 
Rhetorical struggles are most apparent in the field of politics. This book suggests, however, that it is important to take stock of the plurality of usages of the term "Nordic" and analyse the complex interplay between political, academic, cultural and commercial rhetoric. The fact that similar notions of efficiency, simplicity, and age-old traditions of liberty can be evoked in discourses claiming to defend Nordic ethnic homogeneity, promoting Nordic democratic values, creating a Nordic cuisine or selling Nordic crime fiction points towards a certain transferability of the rhetoric of Nordicness from one discourse to another. For example, in his chapter on Nordic noir, Jakob Stougaard-Nielsen argues that the appeal of Nordic crime fiction in the UK from the late 2000s lay precisely in its complex relationship with utopian and dystopian images of the Nordic welfare state.

In emphasising the contested nature of the adjectives "Scandinavian" and "Nordic" the book distances itself from the struggles to define the essence or true nature of the Nordic region and its political and cultural characteristics. Instead, we embrace a constructivist approach akin to the theoretical premises of the discussion on "historical regions." 17 As such, we build on previous studies of the Nordic region such as the seminal The Cultural Construction of Norden, the studies of the "images" of Norden, as well as the more recent discussion on "Nordic branding." 18 Our ambition, however, is to advance beyond a quest for structures or elements that made the Nordic region (the free Nordic peasant, egalitarian education, Lutheranism or Social Democracy), or the ways in which these elements or others were promoted as part of a Nordic brand, and to focus instead on the "speech acts" through which these elements were appealed to (or reject-

17 Troebst, "Introduction;" Todorova, Imagining the Balkans; Todorova, "Spacing Europe"; Diana Mishkova, Beyond Balkanism, the Scholarly Politics of Region Making (London: Routledge, 2018); Mishkova and Trencsényi, European Regions and Boundaries.

18 Sørensen and Stråth, The Cultural Construction of Norden; see also Árnason and Wittrock, Nordic Paths to Modernity; Peter Stadius, Resan till norr: Spanska Nordenbilder kring sekelskiftet 1900 (Helsingfors: Finska Vetenskaps-societeten, 2005); Jonas Harvard and Peter Stadius, "Conclusion: Mediating the Nordic Brand - History Recycled," in Communicating the North: Media Structures and Images in the Making of the Nordic Region, ed. Jonas Harvard and Peter Stadius, The Nordic Experience (Aldershot: Ashgate, 2013), 319-332; Christopher S. Browning, "Branding Nordicity: Models, Identity and the Decline of Exceptionalism," Cooperation and Conflict 42, no. 1 (2007): 27-51, doi:10.1177/0010836707073475; Louis Clerc, Nikolas Glover, and Paul Jordan, eds., Histories of Public Diplomacy and Nation Branding in the Nordic and Baltic Countries: Representing the Periphery (Leiden: Brill, 2015); Svein Ivar Angell and Mads Mordhorst, "National Reputation Management and the Competition State: The Cases of Denmark and Norway," Journal of Cultural Economy 8, no. 2 (2015): 184-201, doi:10.1080/17530350.2014.885459. 
ed) through the use of the adjective "Nordic."19 As such, it is not the making of Norden, but the political and cultural struggles over "the Nordic" that lie at the heart of the book.

We suggest that the rhetoric of Nordicness needs to be analysed by unpacking the historical layers of experiences and connotations present in language. We do this by bringing together scholars working in various disciplinary backgrounds under a common framework inspired by the tradition of conceptual history (Begriffsgeschichte). ${ }^{20}$ Our starting point is that referring to something as "Nordic" or "Scandinavian" is both a reflection of how something Nordic is seen at a given time and a way of forging a specific view on something as Nordic. Paraphrasing Reinhart Koselleck, we see concepts as both mirrors of and vehicles for historical change. ${ }^{21}$ Together, the historical struggles for defining Nordicness form different layers of meaning that are available for actors who can choose to claim, reject or redefine them in order to make new assertions and form future visions for "the Nordic." Our focus is on phrases where "the Nordic" is used in order to make an explicit claim about Nordic exceptionalism or difference from other regions ("the Nordic model" and "Nordic Noir"). It is, however, important also to acknowledge that even when "the Nordic" is used as a neutral marker indicating merely the geographical extension of its noun (as in "Nordic cooperation" or "The Nordic Society for Phenomenology"), the adjective adds something evaluative or substantial to the noun. It might allude to a wide range of positive features associated with the adjective "Nordic," such as democracy, welfare, pragmatism, openness, but it might also potentially evoke different forms of negative associations: arrogance, self-righteousness, or xenophobia. The rhetorical perspective allows for a more detailed analysis of how particular

19 Quentin Skinner, Visions of Politics: Regarding Method, vol. 1 (Cambridge: Cambridge University Press, 2002), doi:10.1017/CBO9780511790812.

20 Reinhart Koselleck, "Einleitung," in Geschichtliche Grundbegriffe: Historisches Lexikon zur politisch-sozialen Sprache in Deutschland, ed. Otto Brunner, Werner Conze, and Reinhart Koselleck (Stuttgart: Klett-Cotta, 1972); Reinhart Koselleck, “A Response to Comments on Geschichtliche Grundbegriffe," in The Meaning of Historical Terms and Concepts: New Studies on Begriffsgeschichte, ed. Hartmut Lehmann and Melvin Richter (Washington, DC: German Historical Institute, 1996); Skinner, Visions of Politics; Jan Ifversen, "About Key Concepts and How to Study Them," Contributions to the History of Concepts 6, no. 1 (2011), doi:10.3167/ choc.2011.060104; Willibald Steinmetz and Michael Freeden, "Conceptual History: Challenges, Conundrums, Complexities," in Conceptual History in the European Space, ed. Willibald Steinmetz, Michael Freeden, and Javier Fernández Sebastián (New York: Berghahn Books, 2017), doi:10.2307/j.ctvw04kcs.9.

21 Koselleck, "Einleitung." 
agents have seen the Nordic region, thus acknowledging that agency belongs to particular persons and institutions and not discourses as such.

\section{Tensions of Nordicness}

In analysing the motives of individual speech acts that have framed different cultural, social and political items as "Nordic", this book takes stock of many different instances of more or less inventive rhetoric. As noted above, standard accounts of what makes Norden Nordic usually present a number of incongruities and contradictions. In shifting the perspective to a study of the rhetoric of Nordicness, these can be identified and analysed more clearly as tensions arising from the various purposes for which the historical actors use the concept.

\section{Contested Nordic geographies}

The geographical extension of the terms "Scandinavian" and the "Nordic" is, of course, a contested issue in itself. Within the region, the adjective "Scandinavian" (skandinavisk, skandinaavinen, skandinaviskur) is usually, but not always, used to denote something Danish, Norwegian and/or Swedish, whereas "Nordic" (nordisk, pohjoismainen, norræn) tends to include Finland and Iceland as well. In other languages and contexts, including in English, "Scandinavian" might be used of all five Nordic nations, or sometimes of just some of them. Historically, the geographical extension of Norden ("the North") has been disputed. In nineteenth-century travel literature, Russia was often included in "the North,"22 while Iceland had an ambivalent position as an example of what Guðmundur Hálfdanarson has labelled "boreal alterity" - on the edge of European civilisation but at the same time associated with the European and Nordic past preserved in its Old Norse literary traditions. ${ }^{23}$

For much of the twentieth century, Sweden was indisputably at the core of the region, the most Nordic of all the Nordic countries. ${ }^{24}$ For Denmark and Nor-

\section{Stadius, Resan till norr.}

23 Guðmundur Hálfdanarson, “Iceland Perceived: Nordic European or a Colonial Other?” in The Postcolonial North Atlantic Iceland, Greenland and the Faroe Islands, ed. Lill-Ann Körber and Ebbe Volquardsen (Berlin: Nordeuropa-Institut der Humboldt-Universität, 2014), 39-66.

24 Jenny Andersson and Mary Hilson, "Images of Sweden and the Nordic Countries," Scandinavian Journal of History 34, no. 3 (2009): 219-28, doi:10.1080/03468750903134681. 
way, being Nordic has largely been equally self-evident, despite these countries' slightly more continental European and transatlantic orientations. By contrast, for Iceland, the turn to Norden was more controversial and demanded a conscious effort in the interwar period. ${ }^{25}$ For Finland, the country's position as a Nordic country was far from evident in the first half of the twentieth century, until the rhetoric of Nordicness gradually became an essential tool to assert its status as part of the West from the 1930 s onwards. ${ }^{26}$ Claims to a Nordic identity have at times formed part of the political rhetoric in Estonia and the Baltic region as a whole, and more recently also in Scotland. ${ }^{27}$ The recent wave of (New) Nordicness, in turn, seems to point in different directions. On the one hand, geopolitical developments and the increased usage of "the Nordic" for branding purposes have furthered the idea of a fixed region consisting of only five Nordic countries and three autonomous regions. ${ }^{28}$ On the other hand, as "the Nordic" has become a brand it refers increasingly to qualities and values rather than geopolitical location or cultural community, and as such questions of the geographical extension of "the Nordic" have become increasingly irrelevant (see Kelting and Stougaard-Nielsen, both in this volume).

The relationship to the outside is, of course, a central aspect of defining the Nordic region, though this demarcation has always been fluid. In the nineteenth century, "Scandinavia" functioned as a means of distinguishing the Danish and Swedish monarchies from other northern powers such as Prussia/Germany and Russia. In early twentieth-century racial discourses, we find the idea of a common Nordic-Germanic people, as opposed to Alpine or Southern races (see Weßel in this volume). From the 1930s, and especially after 1945, Norden was

25 Ragnheiður Kristjánsdóttir, "For Equality or Against Foreign Oppression? The Politics of the Left in Iceland Leading up to the Cold War,” Moving the Social 48 (2012): 11-28, doi:10.13154/ mts.48.2012.11-28; Ragnheiður Kristjánsdóttir, "Facing the Nation - Nordic Communists and Their National Contexts, from the 1920s and into the Cold War," in Labour, Unions and Politics under the North Star: The Nordic Countries, 1700-2000, ed. Mary Hilson, Silke Neunsinger, and Iben Vyff (New York: Berghahn Books, 2017).

26 Max Engman, “Är Finland ett nordiskt land?” Den Jyske Historiker 69-70 (1994).

27 Mikko Lagerspetz, "How Many Nordic Countries?: Possibilities and Limits of Geopolitical Identity Construction," Cooperation and Conflict 38, no. 1 (2003): 49-61, doi:10.1177/ 0010836703038001003; Mart Kuldkepp, "The Scandinavian Connection in Early Estonian Nationalism," Journal of Baltic Studies 44, no. 3 (2013): 313-338, doi:10.1080/ 01629778.2012.744911; Andrew G. Newby, “'In Building a Nation Few Better Examples Can Be Found': Norden and the Scottish Parliament," Scandinavian Journal of History 34, no. 3 (2009): 307-329, doi:10.1080/03468750903134749.

28 Browning, "Branding Nordicity"; Johan Strang, "Introduction: The Nordic Model of Transnational Cooperation?” in Nordic Cooperation: A European Region in Transition, ed. Johan Strang (New York: Routledge, 2016), 1-26, doi:10.4324/9781315755366-1. 
often construed against a German or a European conservative other, or as an exceptional region representing a third way between Western capitalism and Eastern communism. ${ }^{29}$ These uses of "the Nordic" bear a strong similarity to what Reinhart Koselleck called "asymmetrical counter-concepts," that is, conceptual pairs that are defined solely by one part. In Koselleck's heavily laden examples "Hellenes and barbarians," "Christians and heretics," and "humans and non-humans" the second term of the pair receives its meaning from lacking a quality present in the former. "Barbarian" was simply a generic classification put against the specific name of a Hellene. ${ }^{30}$ When it comes to "the Nordic," this use of asymmetrical counter-concepts was most extreme in the racist discourse analysed by Weßel in this volume. But, as shown by Strang, it was also strikingly apparent in the asymmetrical usage of "Europe" to define Nordic cooperation, Nordic democracy or the Nordic welfare state. In the field of culture, the asymmetrical other is usually not articulated (e.g., in the example of Nordic design), but appears in a similar way as something that lacks perceived distinctive Nordic qualities.

\section{Nordicness as simultaneously age old and progressive}

Closely related to these spatial connotations are the temporal dimensions of Nordicness. Recent work on the history of geo-spatial concepts has highlighted how the formation of geographical entities is deeply entrenched in ideas about progress, lagging behind and catching up. ${ }^{31}$ As a whole, the Nordic region has at various points in history been conceived of either as a laggard at the outskirts of European modernity, or as a progressive region at the vanguards of human de-

29 Bo Stråth, "The Swedish Image of Europe as the Other," in Europe and the Other, Europe as the Other, ed. Bo Stråth (Wien: Peter Lang, 2010); Lars Trägårdh, "Sweden and the EU: Welfare State Nationalism and the Spectre of 'Europe," in European Integration and National Identity: The Challenge of Nordic States, ed. Lene Hansen and Ole Wæver (London: Routledge, 2002); see also Strang in this volume.

30 Reinhart Koselleck, Vergangene Zukunft: zur Semantik geschichtlicher Zeiten (Frankfurt am Main: Suhrkamp, 1979).

31 Diana Mishkova and Balázs Trencsényi, "Introduction," in European Regions and Boundaries: A Conceptual History, ed. Diana Mishkova and Balázs Trencsényi (New York: Berghahn Books, 2017); Diana Mishkova and Balázs Trencsényi, "Conceptualizing Spaces within Europe: The Case of Meso-Regions," in European Regions and Boundaries: A Conceptual History, ed. Diana Mishkova and Balázs Trencsényi (New York: Berghahn Books, 2017); Marja Jalava and Bo Stråth, "Scandinavia/Norden," in European Regions and Boundaries: A Conceptual History, ed. Diana Mishkova and Balázs Trencsényi (New York: Berghahn Books, 2017). 
velopment. ${ }^{32}$ As such, the rhetoric of Nordicness has involved a wide range of seemingly contradictory temporal speech-acts. On the one hand, as emphatically shown in Lily Kelting's chapter on New Nordic Food, Nordicness is often used in order to refer to historical, even primordial, features of the Nordic region, relating to nature and landscape. The Viking legacy is often evoked as an "original” pre-nation-state Nordicness. On the other hand, at least since the late nineteenth century the rhetoric of Nordicness has - as indicated above - also often been used to allude to progress, modernity, or even the avant-garde, as opposed to a more traditionalist Europe. ${ }^{33}$ This progressive turn can be dated to "the modern breakthrough" associated with authors like Georg Brandes, Henrik Ibsen and August Strindberg in the late nineteenth century, ${ }^{34}$ to the rise of Social Democracy in the 1930s, or to the designation of the functionalist architecture and modernist design of the mid-twentieth century as "characteristically Scandinavian.”

Perhaps it is precisely this combination of tradition and progress that provides the rhetoric of Nordicness with its suggestive appeal. ${ }^{35}$ The 1930 s rhetoric of Nordic democracy is a case in point. The Social Democrats furnished their own progressive political vision of the future with allusions to its long historical roots. ${ }^{36}$ In this sense, Nordic rhetoric touches upon another Koselleckian theme, the gap between "the space of experience" and "the horizon of expectation." ${ }^{37}$ Today, we see a similar combination of historical tradition and modern solutions in the discourse of gender equality, in which a notion of the strong Nordic woman in early peasant societies is presented as the background to the contemporary position of women in working life, at home and as being in charge of their own bodies (see Pirjo Markkola's chapter in this volume). Building on the French historian François Hartog, it can be suggested that "the Nordic" has be-

32 Stefan Nygård and Johan Strang, "Conceptual Universalization and the Role of the Peripheries," Contributions to the History of Concepts 12, no. 1 (2017): 55-75, doi:10.3167| choc.2017.120105.

33 Tania Ørem, A Cultural History of the Avant-Garde in the Nordic Countries 1925-1950, vol. 1-3 (Leiden: Brill, 2012); Jenny Andersson, "Nordic Nostalgia and Nordic Light: The Swedish Model as Utopia 1930-2007," Scandinavian Journal of History 34, no. 3 (2009): 229-245, doi:.1080/ 03468750903134699.

34 Julie K Allen, Icons of Danish Modernity: Georg Brandes and Asta Nielsen (Seattle: University of Washington, 2012).

35 Carl Marklund and Peter Stadius, "Acceptance and Conformity: Merging Modernity with Nationalism in the Stockholm Exhibition in 1930," Culture Unbound 2, no. 5 (2010): 609-634, doi:10.3384/cu.2000.1525.10235609.

36 Kurunmäki and Strang, “Introduction: 'Nordic Democracy’ in a World of Tensions.”

37 Koselleck, Vergangene Zukunft. 
come increasingly presentist. ${ }^{38}$ Notions like Nordic Noir, Nordic food or even the Nordic model allude to a past that legitimates the present, but do not carry within themselves a promise of a radically better future in the same way as Scandinavianism in the nineteenth century, Nordic democracy in the 1930s, or Nordic cooperation in the Cold War period.

The rhetoric of Nordicness has also been a way of synchronizing the Nordic countries with each other, bringing them together at the same level of development. ${ }^{39}$ It is well known that Nordic comparisons in domestic political debates are often used in order to show that one's own country lags behind the others in some aspect or another, with the purpose of urging political action. Pauli Kettunen, for example, has argued that the notion of the Nordic welfare state in Finland was a matter of immanent critique of Finnish society, where the temporalised rhetoric of "Nordic" represented a horizon of expectation modelled around the Swedish example. If Finland purported to be a Nordic country, it had to follow and catch up with developments in the rest of the region, particularly in Sweden. ${ }^{40}$

In this way, Nordic rhetoric has seldom been a matter of negotiating an average Nordic state of development, but instead it usually refers to the most progressive and advanced solutions in the region. For many decades during the post-war period, Sweden was conceived of as being ahead and by virtue of this defined "the Nordic," giving direction to developments in the other Nordic countries. More recently, this position has been challenged in at least two different ways. On the one hand, it seems as if the other Nordic countries have caught up with and even overtaken Sweden in various fields. As such, "the Nordic model" often appears in international debate as no longer synonymous with the Swedish welfare state, but as the aggregate of cherry-picked features from the different Nordic countries. ${ }^{41}$ On the other hand, there has also been a shift in the political landscape which has meant that an increasing number of people in the region (and abroad) have begun to frame the Swedish example less as a

38 François Hartog, Regimes of Historicity: Presentism and Experiences of Time, trans. Saskia Brown (New York: Columbia University Press, 2015).

39 Helge Jordheim, "Europe at Different Speeds: Asynchronicities and Multiple Times in European Conceptual History," in Conceptual History in the European Space, ed. Willibald Steinmetz, Michael Freeden, and Javier Fernández Sebastián (New York: Berghahn Books, 2017), 139-174, doi:10.2307/j.ctvw04kcs.9.

40 Pauli Kettunen, "The Nordic Welfare State in Finland," Scandinavian Journal of History 26, no. 3 (2001): 225-247, doi:10.1080/034687501750303864.

41 Carl Marklund, "The Nordic Model on the Global Market of Ideas: The Welfare State as Scandinavia’s Best Brand,” Geopolitics 22, no. 3 (2017): 623-639, doi:10.1080/14650045.2016.1251906. 
utopian and more as a dystopian vision of the future. This view has been expressed especially in connection with immigration policy, but in 2020 also with the handling of the Covid-19 pandemic, which has raised concerns that the Swedish welfare state has been wrecked by neoliberal reform. ${ }^{42}$

\section{The interchangeability of "the Nordic" and the national}

It is often argued that the Nordic identity is special because it is complementary, not opposed, to the five different national identities. In other words, Nordicness does not challenge, but is an integral part of Finnishness or Danishness, for example. ${ }^{43}$ This means that there is a certain interchangeability of national adjectives (Danish, Finnish, Icelandic, Norwegian and Swedish) with the word Nordic. Using "Nordic" instead of national adjectives can be an attempt to present something as more primordial than the modern nation-state (see Lily Kelting's chapter in this volume). In Finland, the rhetoric of Nordicness can be a way of incorporating into national history traditions, events, and individuals from the country's long shared history with Sweden. In his chapter on Nordic openness, Tero Erkkilä shows how in 1990s Finland the clergyman and economic thinker Anders Chydenius (1729-1803) was branded as the father of Nordic openness, at least in part because it would have sounded awkwardly anachronistic to label him Finnish.

The substitution of Nordic for the national adjectives may also be a way of associating with the favourable image of the neighbouring countries, or even

42 Mikael Jalving, Absolut Sverige: En rejse i tavshedens rige (København: Jyllands-Postens Forlag, 2011); Bjarne Riiser Gundersen, Svenske tilstander: En reise til et fremmed land (Bergen: Vigmostad \& Bjørke, 2019); Jeanette Björkqvist, "Både Finland och Norge öppnar för att hjälpa," Svenska Dagbladet, December 12, 2020, https://www.svd.se/finland-redo-att-hjalpa-sverigemed-coronavard; Anton Ösgård, “How Privatization Hobbled Sweden's Response To Coronavirus,” Jacobin Magazine, 2020, https://jacobinmag.com/2020/11/sweden-coronavirus-covid-nordic-scandinavia; Peter S. Goodman and Erik Augustin Palm, "Pandemic Exposes Holes in Sweden's Generous Social Welfare State," The New York Times, October 8, 2020, https:// www.nytimes.com/2020/10/08/business/coronavirus-sweden-social-welfare.html; Johan Strang, "Kommentar: Vår älskade dystopi," in Sverigebilden i Norden: En studie i Danmark, Finland, Island och Norge (Stockholm: Svenska institutet, 2021), https://si.se/app/uploads/2021/03/bildenav-sverige-i-norden.pdf.

43 See e. g., Norbert Götz, “Norden: Structures That Do Not Make a Region,” European Review of History: Revue Europeenne d'histoire 10, no. 2 (2003): 323-341, doi:10.1080/ 1350748032000140822; Lene Hansen, “Conclusion,” in European Integration and National Identity: The Challenge of the Nordic States, ed. Lene Hansen and Ole Wæver (London: Routledge, 2001), 212-225. 
hiding more troublesome aspects of the image or reputation of a particular Nordic nation. ${ }^{44}$ For example, at various points in Finnish history the rhetoric of "Nordic democracy" was not only a way of connecting Finland with "the West", but also of smoothing over domestic political tensions and disarming threats from extremist political factions on the right and the left. ${ }^{45}$ Moreover, the rhetoric of Nordicness has also been a way of avoiding explicitly nationalistic rhetoric. In the 1930s, Social Democrats used the same rhetoric of Nordic democracy in order to associate with contemporary trends towards cultural nationalism, without aligning too closely with extreme nationalist voices. ${ }^{46}$ From the 1980s, Swedish Social Democrats mobilised the concept of a Nordic model in response to rising neo liberalism, while references to a Nordic model in the 2010s allowed centre-right politicians to distance themselves from the (Social Democratic) ideological connotations of the Swedish model. ${ }^{47}$

Despite the interchangeability of "Nordic" with national adjectives, the rhetoric of Nordicness has usually included some kind of reference to the other Nordic countries. Especially during the Cold War period, "Nordic" was customarily used either with representation from, or as an appeal to, the other Nordic countries. In an era of nation branding in the new millennium, such references have become less important and the "Nordic" is increasingly used as synonymous with Danishness or Finnishness for example, rather than as a transnational Nordic space.

There are clearly also limits to the interchangeability of the Nordic and the national. It is, for example, unusual to see athletes presented as Nordic, because they are primarily thought of as representing the nation and often in explicit opposition to Nordic “arch-enemies.” In general, Norden seems to have become an

44 Marklund, "The Nordic Model on the Global Market of Ideas."

45 Petri Koikkalainen, "From Agrarian Republicanism to the Politics of Neutrality: Urho Kekkonen and 'Nordic Democracy' in Finnish Cold War Politics," in Rhetorics of Nordic Democracy, ed. Jussi Kurunmäki and Johan Strang (Helsinki: Finnish Literature Society, 2010), doi:10.21435/ sfh.17.

46 Niels Kayser Nielsen, Bonde, stat og hjem: Nordisk demokrati og nationalisme fra pietismen til 2. verdenskrig (Aarhus: Aarhus universitetsforlag, 2009); Kurunmäki and Strang, "Introduction: 'Nordic Democracy' in a World of Tensions”; Nikolas Glover and Andreas Mørkved Hellenes, “A 'Swedish Offensive' at the World's Fairs: Advertising, Social Reformism and the Roots of Swedish Cultural Diplomacy, 1935-1939," Contemporary European History 30, no. 2 (May 2021): 202, doi:10.1017/S0960777320000533.

47 Andreas Mørkved Hellenes, "Tracing the Nordic Model. French Creations, Swedish Appropriations and Nordic Articulations," in The Making and Circulation of Nordic Models, Ideals and Images, ed. Haldor Byrkjeflot et al. (London: Routledge, 2021); Marklund, "The Nordic Model on the Global Market of Ideas;" see also Hilson and Hoctor in this volume. 
increasingly irrelevant framework for sports. Nordic championships are rarely arranged, and Nordic records in various sports are no longer registered or simply deemed irrelevant. Even the Miss Scandinavia beauty pageants were discontinued in 2008. Internal rivalries remain, however, and important clashes between athletes or teams from different Nordic countries can still be framed in the media as "battles of Scandinavia/Norden." That said, even in sports the rhetoric of Nordicness can sometimes be a way of expressing sympathies with (or claiming the success of) an athlete from another Nordic country, as in the case of the Icelandic football success in the 2016 European Championship.

\section{"The Nordic" in different parts of the region}

The rhetoric of Nordicness is used differently and for different purposes in different parts of the region. Sometimes this can cause misunderstandings and frictions between people who all claim to represent "true" Nordicness. In Denmark for example, "the Nordic" has been invoked to stress the distinctiveness of Denmark from the European mainstream, whereas in Finland Nordicness has been a way of cementing Finland's status as a (West) European country. It is beyond the scope of this volume to explore the different uses of Nordicness within the subnational regions of the Nordic countries, but one might expect "the Nordic" to have a different significance in West Jutland, Northern Karelia, Skåne or the Haparanda/Tornio border regions, say, compared to Copenhagen or Helsinki.

Historians of the Nordic welfare state have documented how Nordic cooperation often functioned as an arena where particularly Danish and Swedish politicians quarrelled with each other on various social political issues, thus effectively engaging themselves in a struggle to define "the Nordic welfare state." 48 The rhetoric of Nordicness is thus connected to power hierarchies in the region, where the tendency of monopolising "the Nordic" as a designation for something Danish or Swedish has often generated some irritation in Finland, Iceland and Norway. Examples range from the establishment of the "Nordic Museum" (Nordiska museet) in Stockholm in 1873 to the advertising campaign "Stockholm the capital of Scandinavia” in the first decade of the 2000s. Similarly, in 1874

48 Pauli Kettunen, Urban Lundberg, and Mirja Österberg, "The Nordic Model and the Rise and Fall of Nordic Cooperation," in Nordic Cooperation: A European Region in Transition, ed. Johan Strang, (London: Routledge, 2016), doi:10.4324/9781315755366; Klaus Petersen, "National, Nordic and Trans-Nordic. Transnational Perspectives on the History of the Nordic Welfare State," in Beyond Welfare State Models, ed. Klaus Petersen and Pauli Kettunen (Cheltenham: Edward Elgar Publishing, 2011), 41-64, doi:10.4337/9781849809603.00009. 
Henrik Ibsen complained that Georg Brandes was using "Scandinavian literature" as a name for a small circle of intellectuals in Copenhagen, ignoring writers from other parts of the Nordic region. ${ }^{49}$ Indeed, as shown by Ruth Hemstad in her chapter, in nineteenth-century Norway there was a strong suspicion that the cosy rhetoric of Scandinavia or Norden served only to conceal Swedish and Danish imperialist ambitions, a suspicion that lived on as a Norwegian scepticism of Nordic cooperation throughout much of the latter half of the twentieth century (see also Strang in this volume). More recently, however, Norway has become an enthusiastic promoter of both "the Nordic" and of Nordic cooperation. ${ }^{50}$ This might be related to a fear of being left out when Finland and Sweden joined the EU in 1995 and when the discourse on Baltic Sea cooperation was most intense. ${ }^{51}$ Simultaneously, a case can undoubtedly be made that the oil-generated economic prosperity of recent years has enabled Norwegian actors to indulge in the rhetoric of Nordicness with the self-confidence that was previously confined to Danes and Swedes. ${ }^{52}$

The ambivalent relationship to "the Nordic" is perhaps a more enduring feature of Icelandic political rhetoric, the latest Nordic country to reach full independence (1944). Ragnheiður Kristjánsdóttir has convincingly argued that the Icelandic Social Democratic movement was severely hampered by its "Nordicness" and closeness to its Danish sister party. This meant it remained largely in the shadow of political movements such as the conservatives, agrarians and socialists, who could more easily flourish in a political landscape thoroughly permeated by nationalist discourse. ${ }^{53}$ To be sure, there was also (and continues to be) a similar nationalist hesitation towards the Nordic in Finland, but more

49 Stefan Nygård, "The Southern Prism of the Northern Breakthrough: Georg Brandes and Italy" in Georg Brandes. Pioneer of Comparative Literature and Global Public Intellectual, ed. Jens Bjerring-Hansen, Anders Engberg-Pedersen, and Lasse Horne Kjældgaard (Leiden: Brill, forthcoming).

50 See e.g., Thorvald Stoltenberg, Nordic Cooperation on Foreign and Security Policy, Proposals presented to the extraordinary meeting of Nordic foreign ministers (Oslo, February 2009), https://www.regjeringen.no/globalassets/upload/ud/vedlegg/nordicreport.pdf.

51 Kazimierz Musiał, "Reconstructing Nordic Significance in Europe on the Threshold of the 21st Century," Scandinavian Journal of History 34, no. 3 (2009): 286-306, doi:10.1080/ 03468750903134723.

52 A phenomenon examined and exemplified by the multi-million kroner programme UiO:Nordic at the University of Oslo, which facilitates studies of Nordic issues and the Nordic region from a social science and humanities perspective. See https://www.uio.no/forskning/satsinger/norden/forskning.

53 Kristjánsdóttir, “For Equality or Against Foreign Oppression?”; Kristjánsdóttir, "Facing the Nation - Nordic Communists and Their National Contexts, from the 1920s and into the Cold War.” 
often than not this has been overridden by the geopolitical imperative to keep at a safe distance from the eastern neighbour Russia. For example, while Urho Kekkonen, as a young nationalist intellectual of the Agrarian League had been sceptical of associating Finland with Scandinavia, he was, as President of the Republic during the treacherous Cold War years, eager to emphasise Finland's Nordicness. ${ }^{54}$

In the autonomous regions of Greenland, the Faroe Islands, and Aland, the Nordic discourse has at times had the almost reverse function of strengthening autonomy and weakening the relation to the host countries Denmark and Finland. While the Faroe Islands and Greenland remain underdogs within the Kingdom of Denmark, the Nordic context may provide them with an arena for exerting sovereignty. In concrete terms, the Nordic Council, where the Faroe Islands and Åland have been members since 1970 and Greenland since 1984, has become an important institutional arena for (para-)diplomacy for these autonomous regions. ${ }^{55}$

\section{The rhetoric of Nordicness within the region and abroad}

The rhetorical appeal of Scandinavia outside the region can be traced to the nineteenth century in certain contexts, ${ }^{56}$ but became firmly established from the 1930s on. It has even been argued that the very idea of Norden as a distinct region has been produced abroad, or at least in close dialogue with foreign discourses. ${ }^{57}$ From the 1980 s this was expressed in references to a Scandinavian or

54 Koikkalainen, "From Agrarian Republicanism to the Politics of Neutrality."

55 Sarah Stephan, "Making Autonomies Matter: Sub-State Actor Accommodation in the Nordic Council and the Nordic Council of Ministers. An Analysis of the Institutional Framework for Accommodating the Faroe Islands, Greenland and Åland within 'Norden,"” European Diversity and Autonomy Papers EDAP 3 (2014), http://www.eurac.edu/edap; Hasan Akintug, "The Åland Islands Meet European Integration: Politics of History and the EU Referendums on Åland” (MA diss., University of Helsinki, 2020), https://helda.helsinki.fi/handle/10138/318984.

56 Andrew Newby, "'One Valhalla of the Free': Scandinavia, Britain and Northern Identity in the Mid-Nineteenth Century," in Communicating the North, ed. Jonas Harvard and Peter Stadius (Farnham: Ashgate, 2013), 147-169.

57 Kazimierz Musial, Roots of the Scandinavian Model: Images of Progress in the Era of Modernisation (Baden-Baden: Nomos, 2002); Carl Marklund and Klaus Petersen, "Return to Sender American Images of the Nordic Welfare States and Nordic Welfare State Branding,” European Journal of Scandinavian Studies 43, no. 2 (2013): 245-257, doi:10.1515/ejss-2013-0016; Norbert Götz and Heidi Haggrén, eds., Regional Cooperation and International Organizations: The Nordic Model in Transnational Alignment (London: Routledge, 2009). 
Nordic "model" (or models) available for emulation or export (see Hilson and Hoctor in this volume). Here too, notions of Scandinavia or Norden were often used interchangeably with national labels, with close affinities between the Swedish and Scandinavian models in particular. ${ }^{58}$ While such images were often positive, they were never exclusively utopian: "Scandinavia" could also be used rhetorically to convey dystopian images, such as high rates of taxation or social control on the one hand, or the decadence of secularism and sexual liberation on the other.

In serving highly local purposes abroad, the rhetoric of Nordicness often refers to pointed ideal types - whether utopian or dystopian - where the actual state of affairs in the Nordic countries is almost irrelevant. It may be argued that external circulation sometimes serves to conserve obsolete ideas of what the Nordic countries are. Examples of this might include references to high rates of suicide or the debates on "Scandinavian socialism" in connection with the 2020 US Presidential elections. ${ }^{59}$ The Nordic social democratic welfare state also continues to live on in foreign political debates, despite the fact that its foundations have been transformed in the past decades, particularly in Sweden. ${ }^{60}$ Indeed, in our volume, Mary Hilson and Tom Hoctor show how the idea of the Nordic model has been used positively by both the left and the right in UK politics since the 1990s. Sometimes these foreign uses boomerang back to the Nordic countries themselves, becoming part of branding initiatives or political campaigns based on simplified stereotypes of innate Nordic cultural traits. The Swedish centre-right government's initiative The Nordic Way at the 2011 World Economic Forum in Davos is a case in point. ${ }^{61}$

While it is self-evident that the images of Norden within the region and outside it are not the same, the rhetorical perspective can be a useful way of exploring the connections and interplay between foreign and domestic visions of Nordicness. If notions like the Nordic model are invented to serve particular local purposes in British, German or American contexts, the Nordic appropriation of this rhetoric shows that the reception is not passive and that actors in the region actively use the brands for their own purposes. More recently, terms like Nordic

58 Hellenes, "Tracing the Nordic Model."

59 Carl Marklund and Byron Zachary Rom-Jensen, "Vanishing Scandinavian 'Socialism' in the 2020 US Election,” 2020, https://nordics.info/show/artikel/scandinavias-vanishing-socialism-inthe-2020-us-election.

60 Jenny Andersson, “Drivkrafterna bakom nyliberaliseringen kom från många olika håll,” Respons, no. 1, 2020, http://tidskriftenrespons.se/artikel/drivkrafterna-bakom-nyliberaliseringenkom-fran-manga-olika-hall.

61 Harvard and Stadius, "Conclusion: Mediating the Nordic Brand - History Recycled." 
noir and New Nordic Food have gained in popularity in, for example, Britain and Germany, which, in turn has led to an increased awareness of a common genre (and marketing possibilities) among Nordic authors and publishers (see Stougaard-Nielsen and Kelting, both in this volume).

The rhetoric of Nordicness is often used to distinguish particular features of the region, but it can also be an appeal to something higher or universal. Talking about the welfare state as Nordic rather than Norwegian or Swedish gives it the character of being something more eminent than a contingent result of a series of domestic political decisions. It becomes a "model" which, paradoxically, is at the same time culturally anchored and universal, and as such replicable by others (see Hilson \& Hoctor in this volume). The recent rhetoric of Nordic values can be seen as a similar attempt to put a partisan position beyond political contestation. ${ }^{62}$ The idea that there are values that are commonly shared by people in the region either exaggerates the homogeneity of the populace or speaks of values on such an abstract level that they cannot in any way be regarded as belonging exclusively to Norden. Indeed, one would be hard-pressed to tell the difference between Nordic, European or Western values. It seems that all of these three rhetorical tropes evoke an imaginary of shared values that may be threatened by an equally imagined other. Nordic values also seem to be inherent to Norden regardless of the conflicted history of the region, the asymmetrical relations between the five countries or their complicated relationship to the three autonomous regions, or indeed the political tensions of contemporary politics (are Nordic values social democratic, neoliberal or national conservative?). Much of the universalising character of the notions of the Nordic model and Nordic values is arguably drawn from the nouns "model" and "values," but the modifier "Nordic" provides a rhetorical edge in placing them outside the realm of national politics.

\section{The historical layers of Nordic rhetoric}

This book contains eight case studies purposely chosen in order to give a broad account of the rhetoric of Nordicness in various fields of culture, society and politics, from the nineteenth century to the present. Although they all take their starting point from the common theoretical foundation laid out above, they also represent different scholarly disciplines and offer standalone contributions to debates associated with the individual themes of their chapters. Thus, some of

62 Klaus Petersen, "Nordiske værdier: et kritisk reflekterende essay," in Meningen med föreningen, ed. Henrik Wilen (København: Föreningarna Norden, 2019), 73-83. 
them emphasise analyses of long-term diachronic change in the use of concepts, whereas others are more inclined to analyse rhetoric in individual speech acts or study the political implications of particular discursive frameworks.

In chapter 2, Ruth Hemstad explores the political visions attached to notions of "Scandinavian unity" and "Scandinavian sympathies" in the nineteenth century as well as the conceptual struggles between Swedish and Danish definitions of Scandinavia in the nineteenth century. Merle Weßel, in chapter 3, explores the interplay between American and Nordic uses of the term "Nordic race" in the interwar period. These chapters are followed by investigations of two key notions of Cold War Nordicity. In chapter 4, Mary Hilson and Tom Hoctor discuss the concept of a Nordic model as an interplay between foreign and Nordic discourses from the 1930s onwards, analysing in particular the role of the Nordic model in British politics during the 2000s. Johan Strang examines the shifting implications of Nordic cooperation from 1952 to the 2000s in chapter 5. Chapters 6 and 7 probe more deeply into the 1990s as a turning point for a new rhetoric of Nordicness within Europe. Pirjo Markkola discusses how gender equality became framed and branded as "Nordic" in the 1990s, and Tero Erkkilä describes how openness and transparency were turned into features of Nordic political culture in a period of Europeanisation in the late 1990s and early 2000s, especially in Finland. The final two chapters focus on the recent wave of Nordic branding in the field of culture. In chapter 8 Lily Kelting studies "New Nordic Food" with its references to a primordial and masculine Nordicness, showing how the Nordicness of New Nordic Food paradoxically became de-territorialised and universalised. Jakob Stougaard-Nielsen explores how the Nordicness of Nordic crime fiction became part of the British longing for a lost welfare paradise - a borealist nostalgia.

The volume is not intended as a final or complete account. Many additional cases could have been included (e.g., Nordic design, the Nordic welfare state, and Nordic peace/neutrality). Moreover, most of the examples refer to uses of the rhetorics of Nordicness within the region or in English-language contexts outside it, with little attention paid to how the concept is used in other languages. Collectively, however, the book enables us to draw some conclusions regarding not only the main tensions, but also the historical layers present in the Nordic rhetoric. Overall, the rhetorical approach challenges us to rethink earlier chronologies of what makes Norden Nordic. Our aim is not necessarily to question the long roots of features that can be seen as Nordic, but to highlight critical moments when these characteristics were conceptualised as Nordic. Discussions of the region's cultural distinctiveness often trace these to the Reformation and the early modern period, culminating with the nineteenth-century Scandinavian- 
ist project, ${ }^{63}$ but if we consider the contestation and framing of the Nordic from the point of view of discourse, the nineteenth century was the starting point for when the rhetoric of Nordicness became politically and culturally laden. The same goes for many of the key institutions of Nordicness. For example, histories of Nordic cooperation usually begin with references to the nineteenth century or earlier, but the real breakthrough of the rhetoric of Nordic cooperation can arguably be found in the interwar and Cold War eras (see the chapter by Strang). Similarly, scholars disagree over whether the roots of the Nordic welfare state can be traced to early modern Lutheranism or to institutional developments in the short twentieth century, but the rhetoric of the Nordic welfare state originates in the 1990s (see below). ${ }^{64}$ Accounts of Nordic openness usually go back to the eighteenth century, but the rhetorical account highlights the post-Cold War period (Erkkilä in this volume).

\section{The nineteenth and early twentieth centuries: Scandinavianism and the making of the rhetoric of exceptionality}

There are Scandinavian language examples of nordisk used as a denominator for the Scandinavian Peninsula from the seventeenth century on. For instance, the commission dealing with the incorporation of Skåne into the Swedish realm after the Peace of Roskilde in 1658, referred in a letter to the possibility of uniting "the three Nordic (nordisk) realms under one crown." 65 The term was also used outside the region. Eighteenth-century British discourse on the Northern powers denoted the Danish and Swedish realms, but often also included Russia and

63 For influential examples, see Sørensen and Stråth, The Cultural Construction of Norden; Uffe Østergaard, "The Geopolitics of Nordic Identity: From Composite States to Nation States," in The Cultural Construction of Norden, ed. Øystein Sørensen and Bo Stråth (Oslo: Scandinavian University Press, 1997), 25-71; Henrik Stenius, "Nordic Associational Life in a European and an InterNordic Perspective," in Nordic Associations in a European Perspective, ed. Risto Alapuro and Henrik Stenius (Baden-Baden: Nomos, 2010), 29-86, doi:10.5771/9783845225944-29.

64 Tim Knudsen, ed., Den nordiske protestantisme og velfærdsstaten (Århus: Aarhus universitetsforlag, 2000); Robert H. Nelson, Lutheranism and the Nordic Spirit of Social Democracy: A Different Protestant Ethic (Aarhus: Aarhus University Press, 2017), doi:10.2307/j.ctv62hgm7; Niels Finn Christiansen et al., eds., The Nordic Model of Welfare: A Historical Reappraisal (Copenhagen: Museum Tusculanum Press, 2006).

65 Svenska Akademiens ordbok (SAOB), accessed June 1, 2021, https://www.saob.se/; Lauritz Weibull, "Efter Roskilde fred. Ur skånska kommissionens och Taubenfelts bref till Kungl. Maj: T 1658-1660,” Historisk Tidskrift För Skåneland 1, no. 4-6 (1901): 239. 
Prussia. ${ }^{66}$ Nevertheless, the discourse on the Northern realms at this time does not come across as common or particularly charged with connotations other than purely geographical. This holds both for intra-Scandinavian conceptualisations as well as for external descriptions of the North.

It was in the nineteenth century, in the context of intensified nation building, that "Scandinavian" and "Nordic" gained a politicised future orientation. ${ }^{67}$ This happened primarily within the region itself and especially from the $1830 \mathrm{~s}$ onwards, when the rhetoric of Scandinavian and Nordic was geared towards creating Nordic unity in the spirit of Scandinavianism. Meetings with Danish and Swedish students as well as literary projects, such as Frederik Barfod's Brage og Idun (from 1839) became outlets for Scandinavian unity. Norwegian voices were seldom as loud as those of Swedish and Danish protagonists, and as shown by Hemstad in this volume, the Norwegians were wary that the rhetoric of Scandinavia was a means to subordinate Norway under Swedish rule. Even in Finland, which was peripheral to the cause, voices for Scandinavianism were heard. Emil von Qvanten's Fennomani och skandinavism from 1855 was a critique of political and cultural developments in Finland after its incorporation into the Russian empire in 1809 and proclaimed a Scandinavian orientation. It lamented the Finnish disconnection to "Scandinavian civilization" (Skandinavisk bildning), thus rhetorically coupling Finland's Swedish heritage to something larger. Finland had become disassociated from Scandinavia but could be reconnected with it. ${ }^{68}$

It is, however, important to emphasise the complex and intertwined relationship between Scandinavianism and nationalism in the context of nineteenthcentury romanticism. "Nordic mythology" was a common legacy of the region and in this way the discourses on skandinavisk and nordisk became key parts of the national movement, particularly in Denmark and Sweden. Indeed, the Swedish national anthem celebrates "Norden" rather than "Sweden". Similarly, the pastor and educationalist N.F.S. Grundtvig, the central figure in the Danish

66 Sophie Holm, Diplomatins ideal och praktik: Utländska sändebud i Stockholm 1746-1748 (PhD diss., Helsingfors Universitet, 2019).

67 Ruth Hemstad, Fra Indian Summer til nordisk vinter: Skandinavisk samarbeid, skandinavisme og unionsoppløsningen (Oslo: Akademisk publisering, 2008); Ruth Hemstad, "Scandinavianism. Mapping the Rise of a New Concept," Contributions to the History of Concepts 13, no. 1 (2018): 1-21, doi:10.3167/choc.2018.130102.

68 Emil von Qvanten, Fennomani och Skandinavism: Om Finland och dess sednaste utveckling (Stockholm: Zachrish Haeggerström, 1855), 31. 
national awakening, was also a spokesperson of Scandinavian and Nordic cultural unity. ${ }^{69}$

For most of the nineteenth century, the terms nordisk and skandinavisk were usually used interchangeably in Danish, Norwegian and Swedish, but Scandinavian was more commonly used in conjunction with political visions of the period and was therefore the term that had a stronger mobilising effect. This changed gradually towards the end of the century. Nordisk became readily more common and gained more political salience. ${ }^{70}$ By the early twentieth century nordisk had become the more dominant term for inter-Nordic political cooperation and mobilisation, while skandinavisk mainly lived on in the names of publications as well as cultural and literary connections.

The terminological shift echoes a distinction sometimes made between the era of Scandinavianism in the nineteenth century and the age of Nordism in the twentieth. In this distinction, the former is seen as a pan-national movement or even an ideology and the latter designated as political and civic cooperation. ${ }^{71}$ Nordism was void of attempts to unify the Nordic nations in a federal structure, but was embodied instead in collaboration, first in civil society (e.g., the lawyers' meetings since 1872 and the Norden Associations in 1919) and later also at the official state level. ${ }^{72}$ The shift from "Scandinavian" to "Nordic" was particularly relevant for Iceland and Finland, because after 1918 both countries found themselves in new positions of autonomy and independence, respectively, and had to explore different foreign policy alternatives. The issue was contested in both countries, with some Finns calling for a Baltic orientation and some Icelanders hoping for a weaker connection to Denmark. Nonetheless, framing Iceland and Finland as Nordic countries provided a balance: emphasising national uniqueness as part of a Nordic family. ${ }^{73}$ In Denmark, Sweden and Norway, the

69 Østergaard, “The Geopolitics of Nordic Identity”; Eva Danielson and Märta Ramsten, Du gamla, du friska: Från folkvisa till nationalsång (Stockholm: Atlantis, 2013); Jes Fabricius Møller, "Grundtvig, Danmark og Norden,” in Skandinavismen, ed. Ruth Hemstad, Jes Fabricius Møller, and Dag Thorkildsen (Odense: Syddansk universitetsforlag, 2018), 99-120.

70 Hemstad, "Scandinavianism. Mapping the Rise of a New Concept."; see also Hemstad in this volume.

71 Østergaard, “The Geopolitics of Nordic Identity.”

72 Monika Janfelt, Att leva i den bästa av världar: Föreningarna Nordens syn på Norden 19191933 (Stockholm: Carlsson, 2005); Peter Stadius, “Trekungamötet i Malmö 1914. Mot en ny nordisk retorik i skuggan av världskriget,” Historisk tidskrift för Finland 99, no. 4 (December 2014): 369-394; Strang, "Introduction: The Nordic Model of Transnational Cooperation?"

73 Kristjánsdóttir, “For Equality or Against Foreign Oppression?”; Kristjánsdóttir, "Facing the Nation - Nordic Communists and Their National Contexts, from the 1920s and into the Cold War"; Mikko Majander, Pohjoismaa vai kansandemokratia? Sosiaalidemokraatit, Kommunistit ja 
shift from Scandinavian rhetoric to Nordic rhetoric was less loaded with geo-political connotations, meaning that the terms nordisk and skandinavisk could be used as interchangeable and distinct notions alike.

The complicated relationship between "Nordic" and "Scandinavian" was not, however, necessarily reflected in usages outside the region. In German, the term nordisch was applied much more broadly, often including much of German-speaking Europe, and was consequently also used more commonly than the more specific skandinavisch. It was also widely used in National Socialist rhetoric, generating some aversion to describing the Nordic countries as nordisch after the Second World War. ${ }^{74}$ The ambivalence of the terms Norden and nordisch in German also meant that they could be used to describe the Nordic countries (as in die nordische länder), the Nordic countries and the north German areas together (as was the case in Danish tourist marketing in Germany in the 1930s), or they could be used to refer to the north German areas only. The German state of Schleswig-Holstein in 2020, for example, used the slogan "Der echte Norden" (the true north) in its tourist marketing directed to German travellers - much to the amusement of visitors from the Nordic countries who might well have thought that they had monopoly on the term. ${ }^{75}$

In English the story is different, as the term Scandinavian has clearly been the preferred descriptor and for much of the twentieth century the preferred translation for nordisk was Scandinavian. For instance, the Nordisk Andelsforbund founded in 1918 was referred to in contemporary sources from the 1920s and 1930s as the Scandinavian Co-operative Wholesale Society. ${ }^{76}$ The reference work Annual Register (founded 1758) mentions "the so-called Nordic countries" in the 1920s in relation to US migration policies. Writing in 1958, geographer W. R. Mead noted that the term Norden was used within the region, but "is unsatisfactory for world currency." He also noted that different UK institutions used different terms - the Foreign Office had a Northern Department for example,

Suomen kansainvälinen asema 1944-1951 (Helsinki: Suomalaisen Kirjallisuuden Seura, 2004); Kurunmäki and Strang, "Introduction: 'Nordic Democracy' in a World of Tensions."

74 Malte Gasche, Der "Germanische Wissenschaftseinsatz" des "Ahnenerbes" der SS, 1942-1945: Zwischen Vollendung der "Völkischen Gemeinschaft" und dem Streben nach "Erlösung," (Bonn: Verlag Dr. Rudolf Habelt GmbH, 2014); Hans-Jürgen Lutzhöft, Der Nordische Gedanke in Deutschland 1920-1940 (Stuttgart: E. Klett, 1971).

75 Frederik Forrai Ørskov, "In Ideological Transit: German Tourism to Denmark in the 1930s," Journal of Tourism History 11, no. 3 (September 2, 2019): 243-262, doi:10.1080/ 1755182X.2019.1650127; "Urlaub in Schleswig-Holstein - Offizielle Tourismusseite," www.sh-tourismus.de, August 25, 2016, https://www.sh-tourismus.de/.

76 Mary Hilson, The International Co-operative Alliance and the Consumer Co-operative Movement in Northern Europe, c. 1860-1939, (Manchester: Manchester University Press, 2018). 
while the BBC's "Scandinavian section" included Finland - but concluded that the name of the region in English was still largely unresolved. ${ }^{77}$ The term Nordic really caught on in English only after the establishment of the Nordic Council in 1952. A search of the Google Books dataset shows that "Nordic countries" soon surpassed the earlier term "Northern countries" and has gradually increased ever since. Even so, "Scandinavian countries" was more widely used than "Nordic countries" for much of the twentieth century and up to the 1980 s. $^{78}$ One possible explanation of why "Nordic" did not immediately catch on in English, apart from the concept's general unfamiliarity, was its tainted associations from the past: the concept of a "Nordic race" was prevalent in American eugenics discourse in the interwar period, and, of course, in German National Socialism. ${ }^{79}$ Today, these (explicitly) racist connotations have largely been lost. While "the Nordics" in the 1920s and 1930s was used practically exclusively in order to talk about persons assumed to belong to a Nordic race (for example, in the 1939 volume The Races of Europe), the term has in the 2000s returned as a friendly short-hand for the Nordic countries, often used for branding purposes. ${ }^{80}$

Although the discourse of a Nordic race was also present in Norden in the interwar period - for example in the work of Herman Lundborg - its echoes were largely pushed to the margins of the radical right. Indeed, the 1920s and 1930s form a critical juncture when "the Nordic" became politicised and temporalised even more strongly than before, even to the extent that it was the object of political struggles for ownership. Whereas Scandinavianism and Nordism had been largely a liberal bourgeois discourse, the rhetoric of Nordicness in the 1930s was claimed by the labour movement, who used it to provide historical and national legitimacy to their political project. It formed a bridge between the space of experience and the horizon of expectation. If Nordic democracy had strong roots in the age-old traditions of peasant freedom and in popular mobilisation, it was the task of the labour movement to carry the project into its fruition as a social democracy. ${ }^{81}$

77 W. R. Mead, An Economic Geography of the Scandinavian States and Finland (London: University of London Press, 1958), 6.

78 For an indicator of this, see https://books.google.com/ngrams.

79 Merle Weßel, “The Concept of the 'Nordic Race' in German and Nordic Racial-Theoretical Research in the 1920s,” NORDEUROPAforum - Zeitschrift Für Kulturstudien (2016): 29-49, doi:10.18452/8186; See also Weßel in this volume.

80 Carleton Stevens Coon, The Races of Europe (New York: Macmillan, 1939); see e.g., https:// thenordics.com.

81 Ruth Hemstad, “Scandinavianism, Nordic Co-operation and 'Nordic Democracy,"” in Rhetorics of Nordic Democracy, ed. Jussi Kurunmäki and Johan Strang (Helsinki: Finnish Literature So- 
This was also a time when it was important to mark a difference between Norden and Europe, the old continent being plagued by economic, social and political troubles. This view was presented, for example, by Danish Social Democrat Hartvig Frisch in his book Pest over Europa (Plague over Europe). ${ }^{82}$ In 1935, the Swedish Social Democratic Youth organised a "Day of Nordic Democracy" in Malmö, where the Nordic prime ministers gave speeches under the heading of "Nordic democracy" to rally support for democracy against its internal and external threats. Swedish Prime Minister Per Albin Hansson in particular saw an international call for the Nordic democracies as models for other countries. ${ }^{83}$ Thus, referring to the Nordic countries as Nordic became a way of extending the description of national culture and politics. It reframed domestic affairs in a larger Nordic context and, potentially at least, made them more interesting for those outside the Nordic sphere. ${ }^{84}$

The rhetoric of Nordic democracy, freedom, and unity also played an important role during the Second World War. ${ }^{85}$ The threats to the Nordic countries were, however, very different, so when the Finnish philosopher Georg Henrik von Wright in 1941 wanted to frame Finland's alliance with Nazi-Germany and the revenge war against the Soviet Union as a "Nordic struggle," he might have received some sympathies from Swedish conservatives, but very little from Nazi-occupied Denmark and Norway. ${ }^{86}$

\section{Cold War Norden and beyond}

Political developments in the decades after the Second World War left the region divided on crucial issues like defence (NATO members versus non-aligned) and

ciety, 2010), doi:10.21435/sfh.17; Kurunmäki and Strang, "Introduction: 'Nordic Democracy’ in a World of Tensions."

82 Hartvig Frisch, Pest over Europa: Bolschevisme - Fascisme - Nazisme (Copenhagen: Henrik Koppels Forlag, 1933).

83 Jussi Kurunmäki, “'Nordic Democracy' in 1935: On the Finnish and Swedish Rhetoric of Democracy,” in Rhetorics of Nordic Democracy, ed. Jussi Kurunmäki and Johan Strang (Helsinki: Finnish Literature Society, 2010), doi:10.21435/sfh.17.

84 Kurunmäki and Strang, "Introduction: 'Nordic Democracy' in a World of Tensions."

85 Jan Hecker-Stampehl, Vereinigte Staaten des Nordens: Integrationsideen in Nordeuropa im Zweiten Weltkrieg (München: Oldenbourg, 2011).

86 Georg Henrik von Wright, “Sverige och Ryssland," Finsk Tidskrift (1941): 193; Johan Strang, "Georg Henrik von Wright och Ingemar Hedenius: Rollen som intellektuell och analytisk filosof i Finland och Sverige,” in Tankens utåtvändhet: Georg Henrik von Wright som intellektuell, ed. Johan Strang \& Thomas Wallgren (Helsingfors: Svenska litteratursällskapet 2016). 
the economy (repeated failures to create a Nordic customs union and different policies towards European economic cooperation), but this only served to strengthen the rhetoric of Nordicness as a means to display regional unity and to push the institutionalisation of Nordic cooperation forward. Indeed, as noted by Norbert Götz and Heidi Haggren, divisive as it was, the Cold War constellation was in many respects particularly supportive of Nordic affiliation. ${ }^{87}$

The discourse on Nordic cooperation was at the heart of this development, bridging the tension between the idea that the Nordic countries are part of Europe and the idea that they are, simultaneously, distinct from it (Strang in this volume). Nordic rhetoric burgeoned particularly in the names of different institutions and organisations with a transnational Nordic scope and mission - the Nordic Culture Commission (1946), the Nordic Council (1952), Nordisk journalistkursus (1958), Nordisk utredningsserie (1960), the Nordic Culture Fund (1967), the Nordic Council of Ministers (1971), the Nordic Investment Bank (1976), and Nordiska nämnden för alkohol och narkotikafrågor (1978), to name just a few from an abundance of examples. Even if the adjective "Nordic" undoubtedly carried with it many (positive) connotations, it was usually used primarily as a signifier of the geographical domain of the initiatives (see also Markkola in this volume). Indeed, the representative transnational dimension of Nordicness was arguably particularly important during the Cold War period - it was hard for one country to use Nordic or Scandinavian unless the others were also represented. While difficult to prove, this also seems to hold for non-state initiatives in the cultural sector as well as commercial enterprises that were labelled Nordic or Scandinavian in this period, like the Scandinavian Airlines System (SAS) founded in 1946.

The representative transnational dimension of Nordicness was important also in the joint Nordic branding efforts abroad, most notably regarding Scandinavian design. ${ }^{88}$ From the 1950s onwards we find several examples of this which involved an active push by design practitioners and marketers from within the Nordic region as well as a pull particularly from the English-speaking world. Catalogues and marketing items with "Scandinavian design" as a heading were published in Copenhagen, Helsinki and New York. ${ }^{89}$ Although these consis-

87 Götz and Haggrén, Regional Cooperation and International Organizations, 2.

88 Frantz Wilhelm Wendt, Cooperation in the Nordic Countries: Achievements and Obstacles (Stockholm: Almqvist \& Wiksell International, 1981), 330-331.

89 Viggo Sten Møller, ed., Scandinavian Design: Directory of Arts and Crafts Resources in Denmark, Finland, Norway, Sweden, Copenhagen, 1953 (Copenhagen: Langkæær bogtrykkeri, 1953); Ulf Hård af Segerstad, Eward Maze, and Nancy Maze, Scandinavian Design (Helsinki: Otava, 
tently included items of Finnish design, the label "Nordic design" seemed to be used to a much lesser degree, which may be explained by the fact that designers were adapting to English-speaking marketing. In any case, design comes across as an early example of how Nordic brands could be used to make profits outside of the Nordic region, half a century before the rhetoric of New Nordicness.

The end of the Cold War and the accompanying shift in the dynamics between intra-Nordic and extra-Nordic relations was a period of reorientation and even crisis for the notion of Norden as a distinctive region and a turning point in discourses about Norden. The 1990s was a point in time when the rhetoric of Nordicness proliferated as a designation for many things that were being left behind. Rhetorical uses of "the Nordic" surged as a discourse of nostalgia. ${ }^{90}$ The potent example of this is arguably "the Nordic welfare state." While it is well established in both social scientific and historical research that there was something distinctive in the way that the welfare state took shape in the region in the mid-twentieth century, it was actually very rare that the phrase "welfare state" (välfärdsstat, velferdsstat, hyvinvointivaltio) was combined with the adjective "Nordic." In 1978, Stein Kuhnle wrote an article about "the Nordic Welfare States," but that was more an intra-Nordic comparison than an attempt to crystallise a common essence. ${ }^{91}$ In fact, it was not until the 1990s that the phrase "the Nordic welfare state" was propelled into the centre of both academic and political discourse. This followed the publication of Gøsta Esping-Andersen's highly influential study The Three Worlds of Welfare Capitalism. ${ }^{92}$

The same argument could be made for the notions of "Nordic peace" or "Nordic neutrality", which also mushroomed rhetorically precisely when their political relevance was cast in doubt. ${ }^{93}$ While it is certainly true that the Nordic

1961); Erik Höglund et al., "The Revolution in Scandinavian Design," Craft Horizons 18, no. 2 (April 1958), https://digital.craftcouncil.org/digital/collection/p15785coll2/id/4711.

90 Ole Wæver, "Nordic Nostalgia: Northern Europe after the Cold War," International Affairs 68, no. 1 (1992): 77-102, doi:10.2307/2620462.

91 Stein Kuhnle, "The Beginnings of the Nordic Welfare States: Similarities and Differences," Acta Sociologica 21 (1978): 9-35.

92 Gøsta Esping-Andersen, The Three Worlds of Welfare Capitalism (Cambridge: Polity Press, 1990).; see also the chapter by Hilson and Hoctor in this volume. We would like to thank Nils Edling for pointing this out to us.

93 Clive Archer and Pertti Joenniemi, The Nordic Peace (Aldershot: Ashgate, 2003); Hans Mouritzen, "The Nordic Model as a Foreign Policy Instrument: Its Rise and Fall," Journal of Peace Research 32, no. 1 (1995): 9-21, doi:10.1177/0022343395032001002.; see also Douglas Brommesson, "Introduction to Special Section: From Nordic Exceptionalism to a Third Order Priority - Variations of 'Nordicness' in Foreign and Security Policy,” Global Affairs 4, no. 4- 5 (2018): 355-362, doi:10.1080/23340460.2018.1533385; Browning, "Branding Nordicity”; Adrian Hyde-Price, “Epi- 
countries collaborated with each other in the League of Nations and the United Nations, ${ }^{94}$ it was arguably not until the 1990s that the speech act of calling their engagements for world peace or third world development "Nordic" burgeoned. The notion of a "Nordic balance" gained some traction as a justification for Swedish neutrality, but it was mostly used by scholars to describe the Cold War security configuration in the region with the three Nordic NATO members, Swedish neutrality and the special Finnish relationship with the Soviet Union. ${ }^{95}$ The 1963 Finnish initiative of a "Nordic nuclear-weapon-free zone" can be seen as a partisan attempt at utilising the peace connotations of "the Nordic," which largely failed to gain support among the Nordic NATO members.

What accounts for this proliferation of "the Nordic" as a projection backwards in the 1990s? The obvious explanation, highlighted in the chapters by Markkola, Erkkilä and Strang, is that in the 1990s context of Europeanisation, "the Nordic" functioned as a way of articulating a difference from, and later a distinction within, Europe. But another reason is surely the urge to defend something that was perceived as being on the verge of being lost. As the welfare state became challenged, both as an economically viable system during the economic depression, particularly in Finland and Sweden, and as a semi-socialist ideology in a period of liberalisation and marketisation, the adjective "Nordic" turned the welfare state into something more than the result of contingent policies: it became a national and regional legacy that carried obligations into the future. Conversely, however, the rhetoric of Nordicness also served the purpose of concealing change. If Hilson and Hoctor in their chapter show how the pleasant rhetoric of the Nordic model was used by British conservatives to legitimise neoliberal reforms, similar uses of "the Nordic" are also easy to find within the Nordic region itself (see Strang's chapter). The rhetoric of Nordicness also continued to be used in foreign policy, for example as part of campaigns for seats in the United Nations Security Council, even though many scholars point to a significant change of policy. ${ }^{96}$ In 2015, cuts in Finnish foreign aid and tightened refugee policies were legitimised by reference to similar changes in the other Nordic countries. Indeed, as Finnish political scientists Hanna Ojanen and Tapio Raunio ob-

logue: 'Nordicness' - Theory and Practice,” Global Affairs 4, no. 4-5 (2018): 435-443, doi:10.1080/23340460.2018.1497451.

94 Götz and Haggrén, Regional Cooperation and International Organizations.

95 Erik Noreen, "The Nordic Balance: A Security Policy Concept in Theory and Practice," Cooperation and Conflict 18, no. 1 (1983): 43-56, doi:10.1177/001083678301800104.

96 Anders Wivel, "What Happened to the Nordic Model for International Peace and Security?," Peace Review 29, no. 4 (2017): 489-496, doi:10.1080/10402659.2017.1381521. 
serve, “we can see signs of 'Nordicness' turning into a way of legitimizing policies that deviate from the classic picture of what Nordic is." 97

If the 1990s stand out as one of the key turning points in the history of the rhetoric of Nordicness, several articles in this volume suggest that we have experienced another recent juncture, which started around 2005 with the reinvention and redefinition of the Nordic model as discussed by Hilson and Hoctor, and the coinage of "New Nordic" brands within the field of culture and commerce as analysed by Kelting (New Nordic Food) and Stougaard-Nielsen (Nordic Noir). This new rhetoric of Nordicness signifies a turn to a logic of branding where the aim is no longer to overcome regional differences, to learn from each other, or to create a Nordic community, but rather to promote the region and its products through simplified and essentialised notions of "Nordicness". The rise of the Nordic brand has to be understood as part of the growing international interest in nation branding during the first decades of the early twenty-first century, when nation states embraced the idea of having to compete with their reputation in a globalised world economy. Commercial, political and cultural spheres were hybridised in national branding programmes aiming to attract investments and promote export. ${ }^{98}$ With the success of the Nordic countries in various international rankings, and by virtue of its inherent flexibility, the rhetoric of New Nordicness proved a powerful addition to the national brands. Accordingly, the Nordic governments urged the Nordic Council of Ministers to adopt a strategy of region branding to capitalise on a rising global interest in the Nordic region, for example through its promotion of New Nordic Food, as described in Lily Kelting's chapter. ${ }^{99}$

The rise of the Nordic brand and the rhetoric of "New Nordicness" was also the latest example of the "return to sender" phenomenon described by Carl Marklund and Klaus Petersen in relation to mid-twentieth-century discussions about the global circulation of the Nordic welfare state. ${ }^{100}$ The Nordic brand was born from foreign interest in the Nordic region, and as a Nordic domestication of for-

97 Hanna Ojanen and Tapio Raunio, "The Varying Degrees and Meanings of Nordicness in Finnish Foreign Policy,” Global Affairs 4, no. 4-5 (2018): 415, doi:10.1080/23340460.2018.1533386. 98 E. g., Simon Anholt, Competitive Identity: The New Brand Management for Nations, Cities and Regions (London: Palgrave Macmillan, 2007), doi:10.1057/9780230627727.; see Mads Mordhorst, “Nation-Branding og nationalstaten," Den Jyske Historiker 126 (2010): 16-39; Angell and Mordhorst, "National Reputation Management and the Competition State."

99 See also Anna Kharkina, From Kinship to Global Brand: The Discourse on Culture in Nordic Cooperation after World War II (Huddinge: Södertörns högskola, 2013).

100 Marklund and Petersen, "Return to Sender." 
eign discussions about "the Nordic." In this translation process, within the region itself "the Nordic" became increasingly decoupled from the idea of a regional community, instead it became an international label for various phenomena related to the region. Indeed, it was no longer as relevant whether "the New Nordic" represented the whole of the region, an average of the region, or even whether it gave an accurate description of the region. It became a marker of quality instead of location; something prescriptive or even aspirational. ${ }^{101}$

\section{Conclusion: from community to branding?}

The central argument of this book is that the essential features and historical foundations of "Nordicness" are subject to constant deliberation and debate. While there is a lot of valuable constructivist literature describing the political cultures of the Nordic region, very little has been said from a conceptual-rhetorical perspective about "the Nordic" itself. Such a shift in perspective is motivated particularly by the proliferation and fragmentation of the rhetoric of Nordicness during the 2010s. In examining the historical layers of "the Nordic," our book contributes to a historical understanding of the increasing frequency and ambiguity of the current rhetoric of Nordicness. Intended neither as a complete nor a final account, our book allows us to identify some general trajectories and topics for further research.

Crudely put, it seems to us that the Nordic discourse has mutated from one about cultural community to one about political cooperation, and more recently to one about branding. This transformation needs to be analysed in close relation to the complex and often poorly understood interplay between foreign and intra-Nordic uses of "the Nordic." In relation to the former, the English-language context is especially important, not only because of the global significance of English but also because English is so widely used within the Nordic region. A strict division between the outside and inside is not that useful, as many active in the field of discussing and redefining "the Nordic" move across such distinctions with ease. (That includes, of course, the academics who have contributed to this book.) Still, it seems beyond doubt that the dynamic between outside impulses and internal innovations has been crucial for the rhetoric of Nordicness since at least the First World War. It was central to the discourse

101 Pauli Kettunen, "The Conceptual History of the Welfare State in Finland," in The Changing Meanings of the Welfare State: Histories of a Key Concept in the Nordic Countries, ed. Nils Edling, (New York: Berghahn Books, 2019), 225-275; see also Strang in this volume. 
on Nordic democracy in the inter-war era and to the project of building political and institutional cooperation during much of the twentieth century.

It also holds the key for understanding the special nature of the recent wave of New Nordicness associated with the export of Nordic models and brands in the first decades of the new millennium. The first attempts at marketing Scandinavian design or the Nordic social systems were based on a representation of all five countries. As such, the aim was to create and display a cultural-political community and the rhetoric was thus closely related to that of Nordic cooperation. In global circulation, however, this idea of representativity was less important and "the Nordic" was turned instead into a name and brand for various things associated with the Nordic region. It became a quality rather than a regional marker. This usage has been picked up in the region itself, as "the Nordic" has become used with exponential plurality. The New Nordic is no longer about creating something transnationally Nordic, but about highlighting a quality or a special aspect of something local or national. As such, the global success of the Nordic brand has transformed the purpose of the rhetoric of Nordicness within the region: from creating a cultural or political community, to creating an attribute or quality to be used in global markets.

While the interplay between intra-Nordic and extra-Nordic conceptualisations creates a lot of variance in language use, our concern is not to expose or correct misguided images of the Nordic at different times and in various parts of the world. Nor do we partake in a nostalgic attempt to recreate a past when "the Nordic" stood for something simpler than today. Studying the historical layers of current uses of "the Nordic" is important for recognising that the future is ultimately open ended and dependent on political struggles over the key features of what is Nordic. Scholars, politicians and cultural or commercial actors have to appreciate that they have very limited possibilities of managing the ways in which "the Nordic" is used around the world. But more knowledge is certainly needed in order to understand the triggers, logics, and historical layers of the rhetoric of Nordicness in various parts of the world, especially outside Europe and North America. 
